\title{
Traditional Knowledge of Kidney Stones Treatment by Muslim Maiba (Herbalists) of Manipur, India
}

\author{
Mohd Mustaque AHMED ${ }^{1}$, Kumar Potsangbam SINGH ${ }^{2}$ \\ ${ }^{1}$ United College, Lambung, Department of Botany, Chandel-7 95127, Manipur State, India; mustaque.ahmed@rediffmail.com \\ ${ }^{2}$ Manipur University, Centre of Advanced study in Life Sciences, Canchipur-795138, Manipur State, India; kumars_potsangbam@yahoo.co.in
}

\begin{abstract}
This report is the first of its kind from Manipuri Muslims. Currently, kidney stones (urolithiasis) are recorded as being a painful health problem. For this reason, patients and their relatives seek herbal medicines as a prospective treatment for this condition. A survey was carried out in order to list the number of plants employed in solving kidney stones, as well as to record the age groups of the patients. A total of 39 (3.35\%) persons out of 1162 registered by daily patient registration process of local herbal practitioners, between 12 to 70 years of age (S.D. \pm 12 ), were recorded as suffering from kidney stones (urinary calculi). Patients between 31 to 40 , and 41 to 50 suffered the most, while the group consisting of patients of 11 to 20 years of age suffered the least from this problem. A comparative checking of plants used for kidney stone treatment by Muslim and Meitei herbalists of Manipur is also discussed. The present research of kidney stone treatments will be useful for general public and also for the preservation of helpful plants in home gardens.
\end{abstract}

Keywords: conservation, herbalists, kidney stones, muslims, Manipur

\section{Introduction}

The kidneys are one of the most vital parts of our body (Anthea et al., 1993; Kumar et al., 2005; Reilly, 2005). Malfunction of the kidneys due to the blockage of urine by stones causes severe pain (Margaret et al., 2010). This is an important health problem experienced by many people (Singh et al., 1978). In several cases, patients and their relatives seek herbal medicines instead of modern medicines in order to alleviate the problem (Isaacs, 2010). Herbalists narrated that the patients having kidney stone generally experience sudden acute pain at their lower abdomen. Acute pain is due to the stones lodge in the urinary tract; the symptom starts with incessant vomiting (Stamatelou et al., 2003; Schoenstadt, 2008).

There are four types of kidney stones (Fredric and Worcester, 2005). These include calcium, cystine, struvite and uric acid. Calcium is the most common form of kidney stones, while cystine is the least common variety.

Starting with primitive people the use of wild plants in curing various ailments (Salave et al., 2010) is still current. Herbal-cure methods for kidney stones are found in the case of Muslim herbalists of modern time. The present documentation of herbal treatment by Muslim herbalists of Manipur state is the first of this kind.

\section{Materials and methods}

A field survey work and the registration of patients on daily basis of randomly selected 129 days were carried out from January 2006 to April 2008. As such, the same work and methods (Ahmed and Singh, 2006, 2007, 2008, 2009) by formal interviews of informants, herbalists and collection of plants were followed. A total of 39 (3.35\%) persons out of 1162 persons between 12 to 70 years of age (S.D. \pm 12 ) were recorded as suffering from kidney stones. The days were randomly taken, and the patients with kidney stones belong to various ethnic communities, such as Hindus, Meiteis, Pangals or Muslims, Nagas, Kukis, Nepalis etc. Four herbalists from Thoubal district in Manipur state were contacted for the study.

The present study did not consider the record of the modern hospitals as it aimed only to collect traditional information. Methods to cure kidney stones (Prachi et al., 2009) by employing plants are also reported in India. Urinary tract stones, calculi, and kidney stones are the words used for this affliction worldwide, since this is a global health problem. Considering this, the present work of Muslim herbalists was carried out for its urgency to be documented for its validity of treatment of kidney stones by employing herbs. Other attempts to record herbal treatment of kidney stones are made by Bhatt et al. (2000a), Bhatt (2000b) Prachi et al. (2009), Pandey et al. (2005), Sharma and Gupta (2009).

\section{Results and discussion}

The experiences to cure or dissolve, and eliminate kidney stones by Muslim Maiba (herbalists) are commendable. The oral applications of plant decoctions are used. Small stones passing out with urination are brought by 
patients to the herbalists with the hope of finding a herbal cure.

Muslim herbalists in the State of Manipur are popular for their methods of curing kidney stones. They attract a large number of patients every day. The patients between the age of 31 to 40,41 to 50 and 11 to 20 (see Histogram) were recorded as the most affected and least affected group, respectively. A number of plants are used for kidney stone treatment, for which various methods are given (Tab. 1). Several plants (Tab. 1) are used by Muslim Maiba (herbalists) for the treatment of kidney stones.

Continuous boiling of decoctions is recommended because the preparations may develop a bad odor or taste.

The herbalists' experience says that kidney stones are dissolved and they recorded complete cure of them. Herbal treatment increases in the rate of urination. Hence, passing out stones of $1 \mathrm{~mm}$ to $4 \mathrm{~mm}$ size was recorded with urination. Lastly, the resistant stones are treated during a lifetime by oral application of herbal drinks. It seems that the resistant stones cannot be cured.

Muslim Maiba (herbalists) differentially use Heigru (E. officinalis Gaertn.), Hakthikhanbi (M. minuta (G. Forst.) Less.), Long (S. aromaticum (L.) Merr. and Perry), Gul (P. longum L.), Komprek tujombi (E. Aluctuans Lour.), Tezpat (C. tamala L.), Podina (M. arvensis L.), Ootang (B. nutans Wall), Yensil (O. corniculata L.), Karot (M. cocchinchinensis (Lour.) Spreng), Nungjreng peruk (Centella spp.) on medicinal preparation (Nabakishore, 2002) as do the ones Meitei ethnic community. Their methods (Nabakishore, 2002) to cure kidney stones bear a number of similar plants with that of Muslim herbalists. This may be due to their common language, as well as belonging to the same state and the interchange of knowledge. For example, some plants, such as Kihomman (L. ruelloides (Colsm Pen-

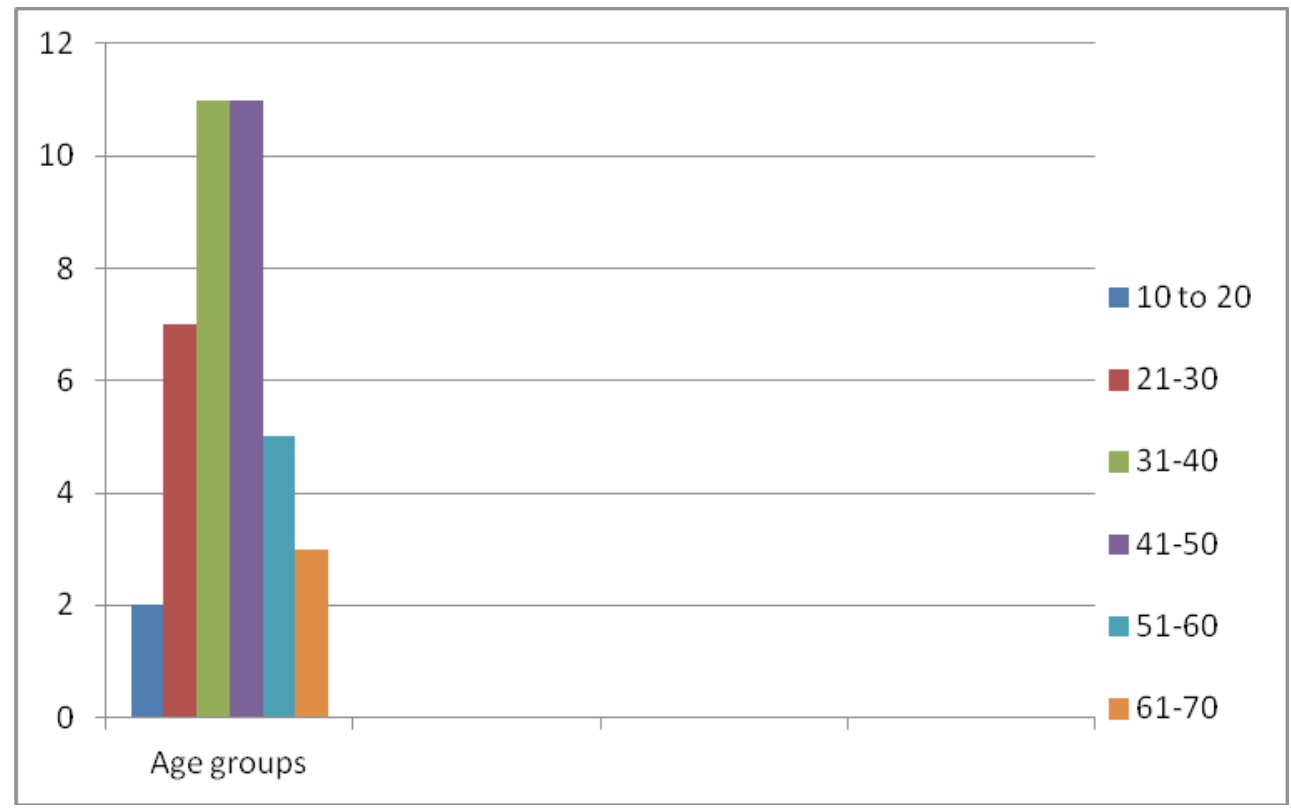

Fig. 1. Histogram showing frequency of kidney stone affected persons belonging to various age class intervals

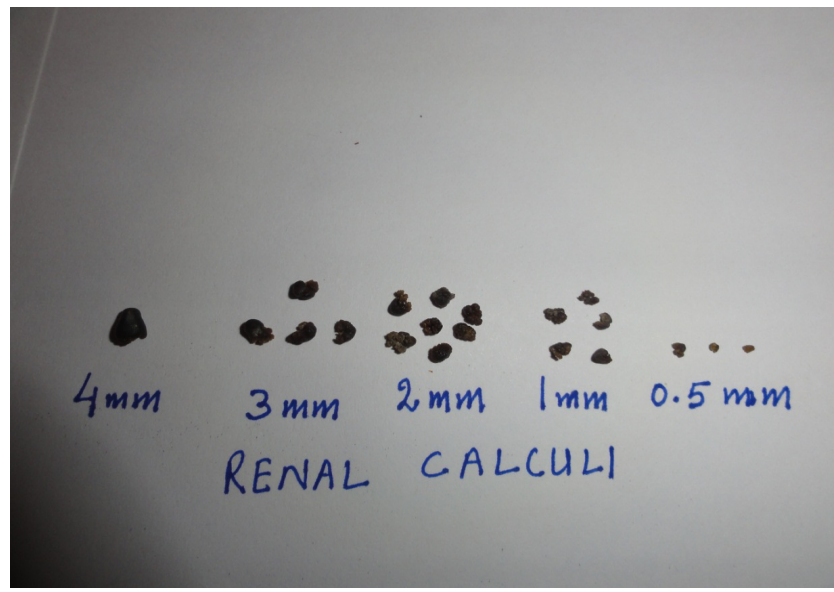

Fig. 2. Different size of renal calculi passed out along with urine after the herbal treatment nell), Heikreng (C. timorensis Span.), Yenam nakuppi (A. odorosum L.), Samukhongpak laba (F. nligerrensis Schltdl. Ex. J. Gay), Heinoujom (A. carambola L.), Mange hei (T. indica L.), Kangphal Langthrei (Eupatorium spp.), Takhellei Angangba (Hedychium aurantiacum Rosc.) are similarly used. However, not all of them are exactly the same. This is due to the unique knowledge inherited by the different communities.

Cross checking of plants used by Muslims for kidney stone treatment in the literature does not reflect their similar uses and methods of preparation in other regions. Some plants as Crataeva nurvala Buch.-Ham., Solanum surattense Burm.f. (Prachi et al., 2009), Crataeva nurvala Buch.-Ham. (Bhatt, 2000b) and Solanum surattense Burm.f. (Bhatt et al., 2000a) have been found to be useful for the treatmet of kindey stones (calculi). Some plants as 
Tab. 1. Traditional herbal treatment methods of kidney stones by Muslim herbalists

\begin{tabular}{|c|c|c|c|c|c|}
\hline Plants & Local name & Plant parts & Quantity & Process & Dose \\
\hline $\begin{array}{l}\text { Emblica officinalis Gaertn. } \\
\text { (Euphorbiaceae) }\end{array}$ & Heigru & Fruits & $\begin{array}{l}250 \text { ml Juice } \\
\text { extraction }\end{array}$ & $\begin{array}{l}\text { Mix extracted juice with } \\
250 \mathrm{ml} \text { lime water }\end{array}$ & $\begin{array}{l}\text { Take } 4 \text { spoons orally } \\
\text { twice daily for } 7 \text { days }\end{array}$ \\
\hline $\begin{array}{c}\text { Myriogyne minuta (G.Forst.) } \\
\text { Less. (Asteraceae) }\end{array}$ & Hakthikhanbi & $\begin{array}{l}\text { Whole } \\
\text { Plant }\end{array}$ & $\begin{array}{c}250 \mathrm{ml} \\
\text { Juice extraction }\end{array}$ & \multirow{4}{*}{ Boiled with 1 liter water } & \multirow{4}{*}{$\begin{array}{l}\text { Drink }(100 \mathrm{ml}) \text { a } \\
\text { day for } 7 \text { days }\end{array}$} \\
\hline $\begin{array}{l}\text { Syzygium aromaticum }(\mathrm{L} .) \\
\text { Merr. and Perry (Myrtaceae) }\end{array}$ & Long & Inflorescence & $\begin{array}{l}1 \text { teaspoonful } \\
\text { powder }\end{array}$ & & \\
\hline Piper nigrum L. (Piperaceae) & Gul & Seed & $\begin{array}{l}1 \text { teaspoonful } \\
\text { powder }\end{array}$ & & \\
\hline $\begin{array}{l}\text { Momordica cochinchinensis } \\
\text { (Lour.) Spreng (Cucurbitaceae) }\end{array}$ & Karot & Seed & $\begin{array}{l}1 \text { teaspoonful } \\
\text { powder }\end{array}$ & & \\
\hline Enhydra fluctuans Lour. (Asteraceae) & $\begin{array}{l}\text { Komprek- } \\
\text { tujombi }\end{array}$ & Whole plant & $5 \mathrm{gm}$ & $\begin{array}{l}\text { Boiled with } 1 \text { liter water } \\
\text { by putting little sugar } \\
\text { candy as sweetener }\end{array}$ & $\begin{array}{l}\text { Drink } 100 \mathrm{ml} \\
\text { daily for } 7 \text { days }\end{array}$ \\
\hline $\begin{array}{l}\text { Fragaria nilgerensis Schltdl. Ex. J. Gay } \\
\text { (Rosaceae) }\end{array}$ & $\begin{array}{l}\text { Samu } \\
\text { khongpak laba }\end{array}$ & Whole plant & $5 \mathrm{gm}$ & \multirow{2}{*}{$\begin{array}{l}\text { Boiled with } 2 \text { litre water by } \\
\text { putting a little sugar candy }\end{array}$} & \multirow{2}{*}{$\begin{array}{l}\text { Drink } 100 \mathrm{ml} \\
\text { daily till cure }\end{array}$} \\
\hline $\begin{array}{c}\text { Lindernia ruellioides (Colsm) Pennell } \\
\text { (Linderniaceae) }\end{array}$ & Kihomman & -do- & $5 \mathrm{gm}$ & & \\
\hline $\begin{array}{c}\text { Celtis timorensis Span. (Ulmaceae) } \\
\text { Put a little salt }\end{array}$ & Heikreng & Leaves & $10 \mathrm{gm}$ & $\begin{array}{l}\text { Boiled with } 2 \text { liters water by } \\
\text { putting a } 2 \text { spoonful of sugar }\end{array}$ & $\begin{array}{l}\text { Drink } 1 \text { tea glass twice } \\
\text { daily for } 10 \text { days }\end{array}$ \\
\hline Cinnamomum tamala L. (Lauraceae) & Tezpat & Leaves & $5 \mathrm{gm}$ & \multirow{2}{*}{$\begin{array}{l}\text { Both plants boiled together } \\
\text { with } 1 \text { liter water by putting } \\
1 \text { teaspoonful sugar }\end{array}$} & \multirow{2}{*}{$\begin{array}{l}\text { Drink } 1 \text { tea glass twice } \\
\text { daily for } 10 \text { days }\end{array}$} \\
\hline $\begin{array}{c}\text { Celtis timorensis Span. } \\
(\text { Ulmaceae })\end{array}$ & Heikreng & Leaves & $5 \mathrm{gm}$ & & \\
\hline Mentha arvensis L. (Lamiaceae) & $\begin{array}{c}\text { Podina/ } \\
\text { Nungshi hidak }\end{array}$ & Leaves & $250 \mathrm{gm}$ & $\begin{array}{l}\text { Crushing leaves with } \\
50 \mathrm{ml} \text { water by using } \\
\text { mortar and pestle }\end{array}$ & $\begin{array}{l}\text { Drink half tea glass } \\
\text { daily for 3-7 days }\end{array}$ \\
\hline Bambusa nutans Wall. (Poaceae) & Ootang & $\begin{array}{c}\text { Bamboo } \\
\text { shoot }\end{array}$ & $250 \mathrm{gm}$ & $\begin{array}{l}\text { Sliced } 250 \mathrm{gm} \text { of shoots } \\
\text { and boiled in } 1 \text { liter water }\end{array}$ & $\begin{array}{l}\text { Drink half tea glass } \\
\text { daily for seven days }\end{array}$ \\
\hline $\begin{array}{l}\text { Eupatorium spp. } \\
\text { (Asteraceae) }\end{array}$ & $\begin{array}{l}\text { Kangphal } \\
\text { langthrei }\end{array}$ & Leaves & $10 \mathrm{gm}$ & $\begin{array}{c}\text { Boiled in } 1 \text { liter water } \\
\text { by putting a little } \\
\text { honey as sweetener }\end{array}$ & $\begin{array}{l}\text { Drink half tea } \\
\text { glass twice daily } \\
\text { for seven days }\end{array}$ \\
\hline $\begin{array}{l}\text { Averrhoea carambola } \mathrm{L} . \\
\quad \text { (Averrhoeaceae) }\end{array}$ & Heinoujom & Fruit & $300 \mathrm{ml}$ & $\begin{array}{l}\text { Put } 2.8 \mathrm{~g} \text { silver element } \\
\text { (used in fusing a gold chain) } \\
\text { into } 300 \mathrm{ml} \text { fruit juice }\end{array}$ & $\begin{array}{l}\text { Drink half tea glass } \\
\text { daily for five days }\end{array}$ \\
\hline $\begin{array}{c}\text { Centella spp. } \\
\text { (Apiaceae) }\end{array}$ & $\begin{array}{l}\text { Nungjreng } \\
\text { peruk }\end{array}$ & Whole plant & $20 \mathrm{gm}$ & \multirow{3}{*}{ Boiled in 1 liter water } & \multirow{3}{*}{$\begin{array}{l}\text { Drink } 1 \text { tea glass } \\
\text { daily for } 7 \text { days }\end{array}$} \\
\hline Celtis timorensis Span. (Ulmaceae) & Heikreng & Leaves & $20 \mathrm{gm}$ & & \\
\hline $\begin{array}{l}\text { Lindernia ruelloides (Colsm) Pennell } \\
\text { (Linderniaceae) }\end{array}$ & Kihomman & Whole plant & $20 \mathrm{gm}$ & & \\
\hline $\begin{array}{l}\text { Allium odorosum } \mathrm{L} . \\
\text { (Alliaceae) }\end{array}$ & $\begin{array}{l}\text { Yenam } \\
\text { nakuppi }\end{array}$ & Leaves & $250 \mathrm{gm}$ & $\begin{array}{l}\text { Boiled in } 1 \text { liter of water and } \\
\text { adding little sugar candy }\end{array}$ & $\begin{array}{l}\text { Drink } 1 \text { tea glass } \\
\text { daily till cure or eat } \\
\text { it with salad items as } \\
\text { much as possible }\end{array}$ \\
\hline $\begin{array}{l}\text { Tamarindus indica } \mathrm{L} . \\
\text { (Caesalpinaceae) }\end{array}$ & Mange hei & Leaves & $20 \mathrm{gm}$ & Boiled with 1 liter water & $\begin{array}{l}\text { Drink } 1 \text { tea glass } \\
\text { daily for seven days }\end{array}$ \\
\hline Oxalis corniculata L. (Oxalidaceae) & Yensil & Whole plant & $100 \mathrm{gm}$ & Boiled with 1 liter water & $\begin{array}{l}\text { Drink } 1 \text { tea glass } \\
\text { daily for seven days }\end{array}$ \\
\hline $\begin{array}{l}\text { Fragaria nilgerrensis Schltdl. } \\
\text { Ex. J. Gay. (Rosaceae) }\end{array}$ & $\begin{array}{l}\text { Samukhongp- } \\
\text { ak laba }\end{array}$ & Whole plant & $100 \mathrm{gm}$ & Boiled with 1 liter water & $\begin{array}{l}\text { Drink } 1 \text { tea glass } \\
\text { daily for seven days }\end{array}$ \\
\hline $\begin{array}{c}\text { Hedychium aurantiacum Rosc. } \\
\text { (Zingiberaceae) }\end{array}$ & $\begin{array}{l}\text { Takhellei } \\
\text { Angangba }\end{array}$ & Stem & $10 \mathrm{gm}$ & Boiled with 1 liter of water & $\begin{array}{l}\text { Drink half tea } \\
\text { glass daily }\end{array}$ \\
\hline
\end{tabular}

Cramp bark (Viburnum opulus L.), Golden rod (Solidago spp.), and Joe-pye weed (Eupatorium maculatum L.) are found to be useful for reducing infection, pain, spasm.

Bhatt et al. (2002a) also reported some plants useful for calculi cure. These plants are Corchorus depressues
(L.), Solanum surattense (Burm. f.), Ascarantha longifolia (Nees.), Ocimum sanctum (L.), Hackelochola granularis (L., Kuntz), etc. There are reports of calculi cure by $\mathrm{Cra}$ - 
taeva nervula Buch.-Ham., Pedalium murex L. (Bhatt, 2000b).

In Manipur, Eupatorium spp. is used by Muslims and Meeteis herbal practitioners. Chinese tea of Hydrangea root (Hydrangea macrophylla (Thunb., Ser.) along with other preparations is reported (citehr.com). Roots and leaves of Boerhavia diffusa (L.) are used for kidney stone treatment (Pandey et al., 2005). Root decoction of Boerhavia diffusa (L.) is useful for kidney stone (Pandey et al., 2005). The wine made from white and red currants has been used for calculous affections (Sharma and Gupta, 2009).

Herbal cure methods in the case study have been claimed to have no side effects. They are cheaper than modern medicine techniques. For this reason, many patients prefer herbal medicines to the modern medicine. This encourages their belief in traditional practices to cure kidney stones. A number of plants are employed as first aid and to cure this health problem which existed since immemorial time. Certain plants have been used with great success to treat kidney stones and this documentation gives an opportunity to conserve useful plants by growing them in home gardens.

\section{Acknowledgements}

We are thankful to the Head of Advanced Study of the Life Sciences Department, Manipur University.

\section{References}

Ahmed MM, Singh PK (2006). Plant-lore with reference to Manipuri proverbs in association with various human affairs of Manipur state. J Curr Sci Dumka 9(1):221-214.

Ahmed MM, Singh PK (2007). Traditional knowledge system of the Muslim community of Manipur state. Indian J Tradit Knowledge 6(2):383-389.

Ahmed MM, Singh PK (2008). Plant-lore with reference to Muslim folksong in association with human perception of plants in Agricultural and Horticultural practices. Not Bot Hort Agrobot Cluj 36(1):42-47.

Ahmed MM, Singh PK (2009). Trading activity and ethnodomestication of Muslim community in Manipur. Not Sci Biol 1(1):14-20.

Anthea M, Hopkins J, McLaughlin CW, Johnson S, Quon Warner M, LaHart D, Wright JD (1993). Human Biology and Health. Englewood Cliffs, Prentice Hall, New Jersey.

Bhatt DC, Mehta DR, Mehta SK, Parmar RP (2000)a. Studies on some Ethnomedicinal plants from Talaja taluka of Bhavnagar district, Gujarat. In: Trivedi PC (Ed.).
Ethnobotany. Aavishkar Publish Distributors, Jaipur, India. Bhatt DC (2000)b. Studies on some Ethnobotanical plants from Saurashtra. In: Trivedi PC (Ed.). Ethnobotany by Aavishkar Publish Distributors, Jaipur, India.

Fredric LC, Evan A, Worcester E (2005). Kidney stone disease. J Clin Invest 115(10):2598-2608.

Isaacs T (2010). Natural ways Eliminate and prevent painful kidney stones. URL:http://www.naturalnews. com/028828_kidney_stones_remedies.html.

Kumar V, Abbas AK, Fausto N, Aster J (2005). Robbins and Cotran pathologic basis of disease. St. Louis, MO, Elsevier Saunders.

Margaret SP, Calhoun E, Curhan GC (2010). Guidelines on Urolithiasis. In: Türk C, Knoll T, Petrik A, Sarica K, Seitz C, Straub M, Traxer O (Eds.). Proceedings of the $9^{\text {th }}$ International Symposium on European Association of Urology.

Nabakishore L (2002). Stone case treatment by medicinal herbs. Asem Shamu Meetei Ed. Kwakeithel Mayaikoibi Ningthoujam Leikai, Imphal, India.

Pandey AK, Patra AK, Shukla PK (2005). Medicinal plants in Satpura plateau of Madhya Pradesh: Current status and future prospects. Indian Forester 131(7):857-883.

Prachi NC, Kumar D, Kasana MS (2009). Medicinal plants of Muzzafarnagar district used in treatment of urinary tract and kidney stones. Indian J Tradit Knowledge 8(2):191-195.

Reilly RF (2005). Nephrology in 30 Days. UNC Press.

Salave AP, Reddy PG, Diwakar PG (2010). Studies on Traditional Ethno-Medico-Flora used by Mahadeo kolis from Ghatsiras areas in Pathardi Taluka of Ahmednagar District (M.S.), India. Asian J Exp Biol Sci Spl:69-74.

Schoenstadt A (2008). Types of kidney stones. Health information brought to life TM. Clinaero. Inc. P1. http:// kidney-stones.emedtv.com/kidney-stones/types-of-kidneystones-p2.html.

Sharma R, Gupta T (2009). Encyclopedia of Medicinal plants. Campus Books International. New Delhi.

Stamatelou KK, Francis ME, Jones CA, Nyberg Jr. LM, Curhan GC (2003). Time trends in reported prevalence of kidney stones in the United States: 1976-1994. Kidney International 63(5):1817-1823.

Singh PP, Singh LBK, Prasad SN, Singh MG (1978). Urolithiasis in Manipur (North Eastern region of India) Incidence of stones. Am J Clin Nutr 31:1519-1525.

URL: http://www.citehr.com/68227-3-ways-dissolve-kidneystones-naturally.html3. Retrieved $1^{\text {st }}$ feb. 2010. 